
\title{
Online journal \\ Combining ability of tropical and temperate inbred lines of popcorn
}

\author{
V.Q.R. da Silva ${ }^{1}$, A.T. do Amaral Júnior ${ }^{1}$, L.S.A. Gonçalves ${ }^{1}$, \\ S.P. Freitas Júnior ${ }^{2}$, L.S. Candido ${ }^{1}$, C. Vittorazzi ${ }^{1}$, L.M. Moterle ${ }^{3}$, \\ R.A. Vieira ${ }^{3}$ and C.A. Scapim ${ }^{3}$ \\ ${ }^{1}$ Universidade Estadual do Norte Fluminense Darcy Ribeiro, \\ Campos dos Goytacazes, RJ, Brasil \\ ${ }^{2}$ Universidade Federal do Ceará, Juazeiro do Norte, CE, Brasil \\ ${ }^{3}$ Universidade Estadual de Maringá, Maringá, PR, Brasil
}

Corresponding author: A.T. do Amaral Júnior

E-mail: amaraljr@uenf.br

Genet. Mol. Res. 9 (3): 1742-1750 (2010)

Received May 3, 2010

Accepted June 26, 2010

Published August 31, 2010

DOI 10.4238/vol9-3gmr900

\begin{abstract}
In Brazil, using combining ability of popcorn genotypes to achieve superior hybrids has been unsuccessful because the local genotypes are all members of the same heterotic group. To overcome this constraint, 10 lines $\left(\mathrm{P}_{1}\right.$ to $\left.\mathrm{P}_{10}\right)$ with different adaptations to tropical or temperate edaphoclimatic environments were used to obtain $45 \mathrm{~F}_{1}$ hybrids in a complete diallel. These hybrids and three controls were evaluated in two environments in Rio de Janeiro State. Grain yield $(\mathrm{GY})$, popping expansion (PE), plant height $(\mathrm{PH})$, ear height $(\mathrm{EH})$, and days to silking (FL) were evaluated in randomized complete blocks with three replications. Significant differences between genotypes ( $\mathrm{P}$ $\leq 0.05$ ) were detected for GY, PE and EH. General combining ability was significant for $\mathrm{EH}, \mathrm{PH}, \mathrm{PE}$, and GY, and specific combining ability was significant only for PE and GY. The most promising inbred lines that improved GY were $\mathrm{P}_{3}$ and $\mathrm{P}_{4}$, unlike $\mathrm{P}_{8}, \mathrm{P}_{9}$ and $\mathrm{P}_{10}$, which improved $\mathrm{PE}$, and $\mathrm{P}_{2}$, which improved both $\mathrm{PE}$ and GY. The additive effects were much more important for PE than for GY. The hybrid combinations
\end{abstract}


gave positive estimates of heterosis for GY but not for PE.

Key words: Zea mays; Edaphoclimatic adaptation; Gene effects; Diallel; Inheritance

\section{INTRODUCTION}

The development of popcorn hybrids depends on parental selection and the identification of heterotic groups (Melani and Carena, 2005). Genitor discrepancies and good gene complementation is necessary to achieve favorable agronomic characteristics (Hallauer and Miranda Filho, 1995). Diallel analysis is a breeding strategy to obtain superior genotypes because it provides consistent results over the years (Amaral Júnior et al., 1999; Cavalcanti et al., 2000; Gouis et al., 2002; Silva et al., 2004; Jaramillo et al., 2005; Marin et al., 2006; Bison et al., 2007). In Brazil, many popcorn studies have been conducted to determine genetic divergence (Pereira et al., 2006, 2008; Dandolini et al., 2008; Vilela et al., 2008; Silva et al., 2009; Trindade et al., 2010) in conjunction with the additional efforts in cytogenetics (Ricci et al., 2007), seed quality (Moterle et al., 2008), agronomic responses (Vendruscolo et al., 2001; Scapim et al., 2010), plant pathology (Vieira et al., 2009a), and the evaluation of breeding methods (Rangel et al., 2007, 2008; Arnhold et al., 2009; Freitas Júnior et al., 2009; Amaral Júnior et al., 2010).

Burnham Larish and Brewbaker (1999) were the first researchers to report the diallels of both temperate and tropical lines. Using Griffing's method (1956), these authors evaluated the combining ability for both grain yield and popping expansion through two diallels, in which the first one had six varieties and the other had five North American lines. This classical experiment indicated that popcorn breeders should work with the heterotic groups ' $\mathrm{Su}$ perGold' and 'Japanese Hulless' under tropical conditions. The same authors also found that the dominant genes were important for improving the crop yield and the components of seed production, and that the additive effects were important for improving popping expansion.

In Brazil, diallel experiments with popcorn are still incipient, and they are based on varieties from heterotic groups with tropical adaptations (Andrade et al., 2002; Freitas Júnior et al., 2006; Scapim et al., 2002, 2006; Miranda et al., 2008; Rangel et al., 2008; Vieira et al., 2009b; Silva et al., 2010). Miranda et al. (2008) reported that the small genetic variability for popping expansion has made it difficult to obtain superior hybrids from the national varieties. Therefore, there is an enormous need for lines from heterotic groups adapted to different environments to investigate the gene effects on grain yield and popping expansion, and to produce hybrids with a high degree of genetic diversity.

The objective of the present study was to evaluate the combining ability of 10 popcorn lines from tropical, temperate and semi-temperate germplasms by diallel crossing.

\section{MATERIAL AND METHODS}

\section{Hybrid combinations}

In March 2007, 10 pre-selected lines from tropical, temperate and semi-temperate lines were crossed in a complete diallel without reciprocals to obtain $45 \mathrm{~F}_{1}$ hybrids (Table 1). 
Plants of inbred lines were spaced $0.40 \mathrm{~m}$ apart and established in rows $0.90 \mathrm{~m}$ apart. Kraft paper bags were used to collect the pollen grains to pollinate each pair of inbred lines.

\begin{tabular}{|c|c|}
\hline Parental inbred lines & Description of the population from which the inbred lines were obtained \\
\hline$P_{1}(P R 023)$ & From the three-way hybrid 'Zélia', released by Pioneer Seeds; it consists of temperate and tropical inbred lines. \\
\hline$P_{2}(P R 024)$ & $\begin{array}{l}\text { From the composite with yellow grains 'CMS- } 42 \text { ', released by Embrapa-Maize and Sorghum; it consists of } \\
\text { tropical inbred lines. }\end{array}$ \\
\hline$P_{3}(\mathrm{PR} 036)$ & $\begin{array}{l}\text { From the composite with white grains 'CMS- } 42 \text { ', released by Embrapa-Maize and Sorghum; it consists of } \\
\text { tropical inbred lines. }\end{array}$ \\
\hline $\mathrm{P}_{4}(\mathrm{UEM} \mathrm{J} 1)$ & From South American races in tropical regions. \\
\hline $\begin{array}{l}P_{5}(P R 045-1) \\
P_{6}(P R 045-2) \\
P_{7}(P R 045-3)\end{array}$ & From the three-way hybrid 'Zaeli', which consists of temperate inbred lines. \\
\hline $\begin{array}{l}P_{8}(P R 087-1) \\
P_{9}(P R 087-2) \\
P_{10}(P R 087-3)\end{array}$ & $\begin{array}{l}\text { From the modified one-way hybrid 'IAC112', adapted to tropical regions; it consists of inbred lines from } \\
\text { the open pollinated variety 'South American Mushroom' crossed with inbred lines from the South } \\
\text { American intervarietal hybrid 'Guarani' x 'Amarela'. }\end{array}$ \\
\hline
\end{tabular}

\section{Evaluation of hybrids, parents and control treatments}

In November 2007, the first trial was established at the Colégio Estadual Agrícola 'Antônio Sarlo', Campos dos Goytacazes municipality, Northern Rio de Janeiro, Brazil (21 ${ }^{\circ} 45^{\prime}$ ' S, $41^{\circ} 20^{\prime}$ ' $\mathrm{W}$ and altitude of $11 \mathrm{~m}$ ), and the second trial was established at the PESAGRO-RIO, Itaocara municipality, Northwestern Rio de Janeiro State, Brazil ( $21^{\circ} 39^{\prime} \mathrm{S}, 42^{\circ} 04^{\prime} \mathrm{W}$ and altitude of $60 \mathrm{~m}$ ).

Under both environmental conditions, the trials were conducted in randomized complete blocks with three replications in which the treatments with $45 \mathrm{~F}_{1}$ hybrids from the 10 lines were compared with three commercial popcorn hybrids that have high potential for crop yield and popping expansion [(IAC112, IAC125 (released by the Agriculture Institute at Campinas, SP, Brazil), and Zélia (released by Pioneer)]. The experimental plots had rows $10.0 \mathrm{~m}$ long, spaced $0.90 \mathrm{~m}$ apart, and every plant in a row was set $0.20 \mathrm{~m}$ apart.

\section{Agronomic traits}

Grain yield (GY) in $\mathrm{kg} /$ ha was evaluated after hand-harvesting the ears with a moisture content of about $17 \%$, which were then dried to $15 \%$. The moisture content was determined according to the standard method of the International Seed Testing Association, which recommends the use of a circulating air oven at $105 \pm 3^{\circ} \mathrm{C}$ for $24 \mathrm{~h}$ with three replications. Popping expansion (PE) was reported as $\mathrm{mL} / \mathrm{g}$, and determined from six $30.0 \mathrm{~g}$ samples per treatment, popped in a Panasonic microwave oven Model NN-S65B at $1000 \mathrm{~W}$ for $3 \mathrm{~min}$. The grain volume for popping expansion was collected from the mid portion of every ear. Grain samples weighing $1.0 \mathrm{~kg}$ and with moisture content of $14 \%$ were safely stored. The average plant height (PH) was measured from the ground level to the flag leaf collar. The ear height (EH) was measured from the ground level to the uppermost ear-bearing node. The data were collected from six competitive plants per plot. Finally, we determined the number of days to silking (FL). 


\section{Statistical analysis}

Levene's test and Kolmogorov-Smirnov's method were used to assess the homogeneity of variances and the normal distribution of errors, respectively. Data transformation was not necessary. The presence of homogeneity in the residual variances between the environments was examined by the F-maximum test at 5\% of probability. Thereafter, the data from both sites were evaluated by combined analysis of variance (ANOVA) from which the sum of squares for the treatments was decomposed into general (GCA) and specific combining abilities (SCA). Treatments and environments were analyzed as random effects. Interactions with the environments were estimated by Griffing's method (Model II). The genetic-statistical analyses were carried out by the Genes program (Cruz, 2006).

\section{RESULTS}

\section{Mean values of traits and the significance of statistical procedures}

For all traits, the F-test did not disclose heterogeneity $(\mathrm{P}<0.05)$ for the mean square of errors estimated by the individual analyses, and this fact permitted the combined analysis of environments. Significant differences from the mean squares of genotypes $(P \leq 0.01)$ were detected for GY, PE and EH (Table 2), but not for PH and FL (P > 0.05). The GCA was significant for EH, PH, PE, and GY, and the SCA was significant only for PE and GY. All interactions GCA versus environments and SCA versus environments were significant for all traits, except for PE.

\begin{tabular}{|c|c|c|c|c|c|c|}
\hline \multirow[t]{2}{*}{ Source of variation } & \multirow[t]{2}{*}{ d.f. } & \multicolumn{5}{|c|}{ Mean square of traits } \\
\hline & & EH & $\mathrm{PH}$ & FL & $\mathrm{PE}$ & GY \\
\hline Genotypes (G) & 54 & $0.12^{* *}$ & $0.27^{\mathrm{ns}}$ & $136.52^{\mathrm{ns}}$ & $5.90^{* * *}$ & $3294180.71^{*}$ \\
\hline $\mathrm{GCA}$ & 9 & $0.27^{* * *}$ & $0.47^{*}$ & $57.99^{\text {ns }}$ & $31.80^{* *}$ & $8013432.68^{*}$ \\
\hline SCA & 45 & $0.09^{\text {ns }}$ & $0.24^{\mathrm{ns}}$ & $152.23^{\text {ns }}$ & $0.72^{* *}$ & $2350330.32 *$ \\
\hline Environments (E) & 1 & $2.19^{* *}$ & $14.90^{* *}$ & $84.51^{* *}$ & $0.03^{* *}$ & $7015604.62 *$ \\
\hline $\mathrm{G}$ versus $\mathrm{E}$ & 54 & $0.06^{* *}$ & $0.18^{* *}$ & $112.83^{* *}$ & $0.09^{\text {ns }}$ & $457732.67^{*+1}$ \\
\hline GCA versus $\mathrm{E}$ & 9 & $0.05^{* *}$ & $0.14^{* *}$ & $121.86^{* *}$ & $0.07^{\text {ns }}$ & $608957.12^{* *}$ \\
\hline SCA versus E & 45 & $0.07^{*}$ & $0.18^{* *}$ & $111.02^{* *}$ & $0.10^{\text {ns }}$ & $427487.79^{* *}$ \\
\hline Error & 216 & 0.01 & 0.03 & 4.51 & 0.35 & 83668.84 \\
\hline
\end{tabular}

$\mathrm{GCA}=$ general combining ability; SCA = specific combining ability; d.f. = degrees of freedom; $\mathrm{EH}=$ ear height; $\mathrm{PH}=$ plant height; $\mathrm{FL}=$ days to silking; $\mathrm{PE}=$ popping expansion; $\mathrm{GY}=$ grain yield; $\mathrm{ns}=$ not significant $(\mathrm{P}>0.05)$; ${ }^{* *}$ significant at $\mathrm{P} \leq 0.01$; ; significant at $\mathrm{P} \leq 0.05$.

Grain yield for the inbred lines varied from $1,110.00 \mathrm{~kg} / \mathrm{ha}\left(\mathrm{P}_{1}\right)$ to $1,996.67 \mathrm{~kg} / \mathrm{ha}$ $\left(\mathrm{P}_{3}\right)$, and for the hybrid combinations it varied from $1,223.33 \mathrm{~kg} / \mathrm{ha}\left(\mathrm{P}_{5} \times \mathrm{P}_{7}\right)$ to $3,493.33 \mathrm{~kg} /$ ha $\left(\mathrm{P}_{2} \times \mathrm{P}_{4}\right)$. The hybrid combinations $\mathrm{P}_{2} \times \mathrm{P}_{4}(3,493.33 \mathrm{~kg} / \mathrm{ha}), \mathrm{P}_{1} \times \mathrm{P}_{3}(3,360.00 \mathrm{~kg} / \mathrm{ha}), \mathrm{P}_{2}$ x $\mathrm{P}_{9}(3,166.67 \mathrm{~kg} / \mathrm{ha}), \mathrm{P}_{2} \times \mathrm{P}_{3}(3,033.33 \mathrm{~kg} / \mathrm{ha}), \mathrm{P}_{4} \times \mathrm{P}_{8}(2,976.67 \mathrm{~kg} / \mathrm{ha}), \mathrm{P}_{1} \times \mathrm{P}_{4}(2,973.33$ $\mathrm{kg} / \mathrm{ha})$, and $\mathrm{P}_{3} \times \mathrm{P}_{10}(2,915.00 \mathrm{~kg} / \mathrm{ha})$ demonstrated higher grain yields compared to the control treatments for which Zélia yielded $2,335.00 \mathrm{~kg} / \mathrm{ha}$, IAC112 yielded $1,970.00 \mathrm{~kg} / \mathrm{ha}$, and IAC125 yielded $1,880.00 \mathrm{~kg} / \mathrm{ha}$. 
Popping expansion of the inbred lines varied from $31.90\left(\mathrm{P}_{7}\right)$ to $35.67 \mathrm{~mL} / \mathrm{g}\left(\mathrm{P}_{8}\right)$, and the hybrid combinations varied from $31.43\left(\mathrm{P}_{3} \times \mathrm{P}_{7}\right)$ to $34.83 \mathrm{~mL} / \mathrm{g}\left(\mathrm{P}_{8} \times \mathrm{P}_{10}\right)$. These responses are in contrast to the control treatments in which the popping expansion of IAC112 was 25.90, Zélia was 25.53 and IAC125 was $24.84 \mathrm{~mL} / \mathrm{g}$. In summary, the inbred lines and their hybrid combinations had the highest indices of PE.

The inbred lines had estimates of EH ranging from $0.74\left(\mathrm{P}_{1}\right)$ to $1.13 \mathrm{~m}\left(\mathrm{P}_{4}\right)$, $\mathrm{PH}$ ranging from $1.30\left(\mathrm{P}_{1}\right)$ to $1.86 \mathrm{~m}\left(\mathrm{P}_{4}\right)$ and $\mathrm{FL}$ ranging from $58.33\left(\mathrm{P}_{9}\right)$ to 62.67 days $\left(\mathrm{P}_{6}\right)$. The hybrid combinations had estimates of EH ranging from $0.88\left(\mathrm{P}_{1} \times \mathrm{P}_{7}\right)$ to $1.27 \mathrm{~m}\left(\mathrm{P}_{4} \times \mathrm{P}_{9}\right)$, $\mathrm{PH}$ ranging from $1.06\left(\mathrm{P}_{5} \times \mathrm{P}_{6}\right)$ to $2.07 \mathrm{~m}\left(\mathrm{P}_{7} \times \mathrm{P}_{9}\right)$ and $\mathrm{FL}$ ranging from $41.67\left(\mathrm{P}_{1} \times \mathrm{P}_{4}\right)$ to 60.67 days $\left(\mathrm{P}_{6} \times \mathrm{P}_{8}\right)$.

\section{Average effects of the general combining ability}

Three inbred lines $\left(\mathrm{P}_{2}, \mathrm{P}_{3}\right.$ and $\left.\mathrm{P}_{4}\right)$ were the most outstanding for GY (Table 3 ) because of higher estimates of $\hat{\mathrm{g}}_{\mathrm{i}}$. Therefore, these inbred lines can be used in the development of highyield hybrids unlike $\mathrm{P}_{6}, \mathrm{P}_{7}$ and $\mathrm{P}_{9}$, which had negative estimates of $\hat{\mathrm{g}}_{\mathrm{i}}$, and negative estimates mean poor hybrid responses. The positive estimates of $\hat{\mathrm{g}}_{\mathrm{i}}$ from $\mathrm{P}_{2}, \mathrm{P}_{3}$ and $\mathrm{P}_{4}$ were expected because these inbred lines had the best responses in both environments.

Table 3. Average effects of the general combining ability $\left(\hat{\mathrm{g}}_{\mathrm{i}}\right)$ for five traits evaluated in 10 parental inbred lines of popcorn, in a complete diallel without reciprocals in the two environments of Campos dos Goytacazes and Itaocara, for growing season 2007/2008, Rio de Janeiro, Brazil.

\begin{tabular}{|c|c|c|c|c|c|}
\hline \multirow[t]{2}{*}{ Parental inbred line } & \multicolumn{5}{|c|}{$\hat{\mathrm{g}}_{\mathrm{i}}$ of traits } \\
\hline & GY & $\mathrm{PH}$ & $\mathrm{EH}$ & FL & $\mathrm{PE}$ \\
\hline$P_{1}(P R 023)$ & -216.2670 & -0.1400 & -0.1250 & 1.2940 & -0.2460 \\
\hline $\mathrm{P}_{2}$ (PR 024) & 405.2610 & 0.1080 & 0.0420 & -0.2060 & 0.5350 \\
\hline $\mathrm{P}_{3}^{2}(\mathrm{PR} 036)$ & 513.5390 & -0.0200 & 0.0220 & -0.4140 & -0.6280 \\
\hline $\mathrm{P}_{4}^{3}$ (UEM J1) & 484.2890 & 0.1160 & 0.0980 & -0.3860 & -0.3650 \\
\hline $\mathrm{P}_{5}^{4}(\mathrm{PR} 045-1)$ & -132.1690 & 0.0190 & 0.0180 & 1.1420 & -0.6910 \\
\hline $\mathrm{P}_{6}^{5}(\mathrm{PR} 045-2)$ & -335.2250 & -0.0890 & -0.0320 & -1.1640 & -0.4610 \\
\hline $\mathrm{P}_{7}$ (PR 045-3) & -232.9190 & -0.0370 & -0.0510 & 0.2940 & -0.5450 \\
\hline $\mathrm{P}_{8}(\mathrm{PR} 087-1)$ & -34.7390 & 0.0570 & 0.0430 & 0.6970 & 1.0990 \\
\hline $\mathrm{P}_{9}(\mathrm{PR} 087-2)$ & -276.1970 & -0.0210 & -0.0110 & -1.4000 & 0.4800 \\
\hline $\mathrm{P}_{10}(\mathrm{PR} 087-3)$ & -175.5720 & 0.0070 & -0.0040 & 0.1420 & 0.8220 \\
\hline
\end{tabular}

$\mathrm{GY}=$ grain yield; $\mathrm{PH}=$ plant height; $\mathrm{EH}=$ ear height; $\mathrm{FL}=$ days to silking; $\mathrm{PE}=$ popping expansion.

The estimates of $\hat{\mathrm{g}}_{\mathrm{i}}$ for $\mathrm{PE}$ indicated that $\mathrm{P}_{2}, \mathrm{P}_{8}, \mathrm{P}_{9}$, and $\mathrm{P}_{10}$ were the most suitable inbred lines for producing hybrids with high popping expansion (Table 3), even though $\mathrm{P}_{8}$ had been the most outstanding inbred line. Negative values of $\hat{\mathrm{g}}_{\mathrm{i}}$ for $\mathrm{PH}$ and $\mathrm{EH}$ were found for $\mathrm{P}_{1}, \mathrm{P}_{6}, \mathrm{P}_{7}$, and $\mathrm{P}_{9}$, which meant that these inbred lines tended to reduce the plant height. $\mathrm{P}_{3}$ had a negative estimate of $\hat{\mathrm{g}}_{\mathrm{i}}$ for $\mathrm{PH}$ only, and $\mathrm{P}_{6}$ and $\mathrm{P}_{9}$ were the most promising inbred lines for reducing the number of FL.

\section{Average effects of the specific combining ability}

Two hybrid combinations $\mathrm{P}_{2} \times \mathrm{P}_{9}$ and $\mathrm{P}_{3} \times \mathrm{P}_{7}$ displayed positive estimates of $\hat{\mathrm{s}}_{\mathrm{ij}}$ for GY. These hybrids had at least one superior inbred line with a high GCA. The hybrid combinations $\mathrm{P}_{1} \mathrm{x}$ $\mathrm{P}_{9}, \mathrm{P}_{1} \times \mathrm{P}_{10}, \mathrm{P}_{2} \times \mathrm{P}_{4}$, and $\mathrm{P}_{8} \times \mathrm{P}_{10}$ had positive estimates of $\hat{\mathrm{s}}_{\mathrm{ij}}$ for $\mathrm{PE}$. Two hybrid combinations $\left(\mathrm{P}_{6} \times\right.$ $\mathrm{P}_{9}[\mathrm{PH}=-0.9860$ and $\mathrm{EH}=-0.5620]$ and $\mathrm{P}_{5} \times \mathrm{P}_{8}[\mathrm{PH}=-0.1290$ and $\left.\mathrm{EH}=0.0820]\right)$ may be selected to reduce the plant and ear heights (Table 4). Negative estimates of $\hat{\mathrm{s}}_{\mathrm{ij}}$ for FL were found for $\mathrm{P}_{2} \times \mathrm{P}_{6}$, 
$\mathrm{P}_{1} \times \mathrm{P}_{8}, \mathrm{P}_{2} \times \mathrm{P}_{8}, \mathrm{P}_{4} \times \mathrm{P}_{6}$, and $\mathrm{P}_{7} \times \mathrm{P}_{8}$ (Table 4).

Table 4. Estimates of the effects of specific combining ability $\left(\hat{\mathrm{s}}_{\mathrm{ii}}\right.$ and $\left.\hat{\mathrm{s}}_{\mathrm{ij}}\right)$ for five traits evaluated in two environments by a complete diallel.

\begin{tabular}{|c|c|c|c|c|c|}
\hline \multirow{2}{*}{$\begin{array}{l}\text { Effects } \\
\left(\hat{\mathrm{s}}_{\mathrm{ii}} \text { and } \hat{\mathrm{s}}_{\mathrm{ij}}\right)\end{array}$} & \multicolumn{5}{|c|}{ Traits evaluated } \\
\hline & GY & $\mathrm{PH}$ & EH & FL & $\mathrm{PE}$ \\
\hline$\overline{P_{1} \times P_{1}}$ & -1247.0000 & -0.3990 & -0.2040 & 4.0720 & 0.1810 \\
\hline $\mathrm{P}_{1} \times \mathrm{P}_{2}$ & 231.4400 & 0.1260 & 0.0420 & -1.2600 & -0.1570 \\
\hline $\mathrm{P}_{1}^{1} \times \mathrm{P}_{3}^{2}$ & 651.4900 & 0.1410 & 0.0800 & -2.2200 & 0.2870 \\
\hline $\mathrm{P}_{1} \times \mathrm{P}_{4}^{3}$ & 260.7400 & -0.0220 & -0.0120 & -7.0800 & 0.1950 \\
\hline $\mathrm{P}_{1} \times \mathrm{P}_{5}^{4}$ & 353.8700 & 0.0660 & 0.0090 & -0.1090 & 0.0830 \\
\hline $\mathrm{P}_{1}^{1} \times \mathrm{P}_{6}^{5}$ & 153.5900 & 0.1290 & 0.0620 & 2.8630 & -0.6980 \\
\hline $\mathrm{P}_{1} \times \mathrm{P}_{7}^{6}$ & -362.0000 & -0.0440 & -0.0410 & 0.0720 & 0.0700 \\
\hline $\mathrm{P}_{1} \times \mathrm{P}_{8}^{7}$ & 44.7750 & 0.1150 & 0.0320 & -3.3300 & -0.0070 \\
\hline $\mathrm{P}_{1} \times \mathrm{P}_{9}^{8}$ & 671.2300 & 0.1550 & 0.1010 & 0.1000 & 0.4380 \\
\hline $\mathrm{P}_{1} \times \mathrm{P}_{10}^{9}$ & 222.2700 & -0.0970 & 0.0020 & -2.7700 & 0.3030 \\
\hline $\mathrm{P}_{2} \times \mathrm{P}_{2}^{10}$ & -1385.0000 & -0.2100 & -0.1670 & 5.5720 & 0.4920 \\
\hline $\mathrm{P}_{2} \times \mathrm{P}_{3}$ & -18.3600 & -0.0120 & -0.0370 & -1.5500 & -0.7610 \\
\hline $\mathrm{P}_{2}^{2} \times \mathrm{P}_{4}^{3}$ & 409.2200 & -0.0500 & -0.0660 & -0.9140 & 0.2920 \\
\hline $\mathrm{P}_{2}^{2} \times \mathrm{P}_{5}^{4}$ & 46.5110 & 0.0110 & -0.0150 & -2.9400 & 0.0850 \\
\hline $\mathrm{P}_{2}^{2} \times \mathrm{P}_{6}^{5}$ & 177.0600 & 0.1070 & 0.0530 & -3.3000 & -0.0620 \\
\hline $\mathrm{P}_{2} \times \mathrm{P}_{7}$ & 313.9200 & -0.0230 & -0.0160 & -2.5900 & 0.1220 \\
\hline $\mathrm{P}_{2}^{2} \times \mathrm{P}_{8}^{\prime}$ & 83.2470 & -0.2080 & -0.0090 & -3.3300 & -0.3380 \\
\hline $\mathrm{P}_{2}^{2} \times \mathrm{P}_{9}^{8}$ & 908.0300 & 0.1880 & 0.1650 & 0.9330 & -0.0360 \\
\hline $\mathrm{P}_{2}^{2} \times \mathrm{P}_{10}^{9}$ & 352.4100 & 0.0520 & 0.0830 & -1.7700 & -0.1280 \\
\hline $\mathrm{P}_{3}^{2} \times \mathrm{P}_{3}^{10}$ & -1579.0000 & -0.1950 & -0.1200 & 5.8220 & 0.5850 \\
\hline $\mathrm{P}_{3}^{3} \times \mathrm{P}_{4}^{3}$ & -77.3900 & -0.0220 & -0.0260 & -1.8700 & 0.0720 \\
\hline $\mathrm{P}_{3}^{3} \times \mathrm{P}_{5}^{4}$ & 64.0670 & -0.0310 & -0.0280 & -2.5600 & -0.3180 \\
\hline $\mathrm{P}_{3}^{3} \times \mathrm{P}_{6}^{5}$ & 472.1200 & 0.0830 & 0.0690 & 0.4050 & 0.1350 \\
\hline $\mathrm{P}_{3}^{3} \times \mathrm{P}_{7}^{6}$ & 1014.1000 & -0.0210 & 0.0180 & -2.7200 & -0.1390 \\
\hline $\mathrm{P}_{3}^{3} \times \mathrm{P}_{8}^{7}$ & 194.9700 & 0.0190 & -0.0290 & -3.1200 & -0.3920 \\
\hline $\mathrm{P}_{3} \times \mathrm{P}_{9}^{8}$ & 379.7610 & 0.0300 & 0.0310 & -1.0200 & -0.0220 \\
\hline $\mathrm{P}_{3} \times \mathrm{P}_{10}$ & 212.4700 & -0.0260 & 0.0290 & -2.5600 & -0.0310 \\
\hline $\mathrm{P}_{4}^{3} \times \mathrm{P}_{4}^{10}$ & -1593.9000 & -0.2020 & -0.1760 & 5.4330 & 0.3350 \\
\hline $\mathrm{P}_{4} \times \mathrm{P}_{5}^{4}$ & 230.8170 & -0.1700 & 0.0560 & -1.7600 & -0.1480 \\
\hline $\mathrm{P}_{4}^{4} \times \mathrm{P}_{6}$ & 443.0390 & 0.1960 & 0.0830 & -3.7800 & -0.1540 \\
\hline $\mathrm{P}_{4}^{4} \times \mathrm{P}_{7}^{0}$ & 484.0670 & 0.0740 & 0.0580 & -2.2400 & -0.1430 \\
\hline $\mathrm{P}_{4}^{4} \times \mathrm{P}_{8}^{\prime}$ & 369.2200 & 0.0870 & 0.0330 & 0.8490 & -0.7050 \\
\hline $\mathrm{P}_{4}^{4} \times \mathrm{P}_{9}^{8}$ & 503.1780 & 0.1380 & 0.1310 & 2.4470 & -0.0520 \\
\hline $\mathrm{P}_{4}^{4} \times \mathrm{P}_{10}^{9}$ & 298.3860 & -0.0560 & -0.0390 & -2.0900 & -0.0280 \\
\hline $\mathrm{P}_{5}^{4} \times \mathrm{P}_{5}^{10}$ & -304.3900 & -0.0070 & -0.0220 & 2.8770 & 0.4880 \\
\hline$P_{5}^{5} \times P_{6}^{5}$ & -771.3300 & -0.1260 & -0.1000 & 1.8490 & 0.1810 \\
\hline $\mathrm{P}_{5}^{5} \times \mathrm{P}_{7}^{6}$ & -144.4700 & -0.0600 & -0.0130 & -1.2700 & -0.0550 \\
\hline $\mathrm{P}_{5}^{3} \times \mathrm{P}_{8}^{\prime}$ & 110.6780 & -0.1290 & -0.0820 & -1.3400 & -0.1620 \\
\hline $\mathrm{P}_{5}^{5} \times \mathrm{P}_{9}^{8}$ & 365.4700 & 0.1230 & 0.0410 & -2.0800 & -0.3900 \\
\hline $\mathrm{P}_{5} \times \mathrm{P}_{10}$ & 86.5110 & 0.1010 & 0.0430 & -1.1200 & -0.2520 \\
\hline $\mathrm{P}_{6}^{5} \times \mathrm{P}_{6}^{10}$ & -236.6100 & 0.0020 & -0.0340 & 8.6550 & 0.2170 \\
\hline $\mathrm{P}_{6} \times \mathrm{P}_{7}$ & 378.5810 & 0.0610 & 0.0890 & -1.4700 & -0.0150 \\
\hline $\mathrm{P}_{6} \times \mathrm{P}_{8}^{\prime}$ & 218.7330 & 0.1810 & 0.1770 & 3.4610 & 0.1580 \\
\hline $\mathrm{P}_{6}^{0} \times \mathrm{P}_{9}^{8}$ & -906.4700 & -0.9860 & -0.5620 & -24.2000 & 0.0930 \\
\hline $\mathrm{P}_{6} \times \mathrm{P}_{10}$ & 41.2330 & 0.1210 & 0.0650 & 1.3490 & -0.0720 \\
\hline $\mathrm{P}_{7}^{0} \times \mathrm{P}_{7}^{10}$ & -777.8900 & -0.1510 & -0.1210 & 4.2380 & 0.1860 \\
\hline $\mathrm{P}_{7} \times \mathrm{P}_{8}^{\prime}$ & 66.4280 & -0.0170 & -0.0290 & -3.6600 & 0.0420 \\
\hline $\mathrm{P}_{7} \times \mathrm{P}_{9}^{8}$ & -498.7800 & 0.0610 & 0.0450 & 2.9330 & -0.1390 \\
\hline $\mathrm{P}_{7} \times \mathrm{P}_{10}$ & 37.2610 & 0.0410 & -0.0030 & -3.1000 & -0.1150 \\
\hline $\mathrm{P}_{8}^{\prime} \times \mathrm{P}_{8}^{10}$ & -664.2500 & -0.0930 & -0.0940 & 3.4330 & 0.6310 \\
\hline $\mathrm{P}_{8}^{8} \times \mathrm{P}_{9}^{8}$ & -131.9600 & 0.0460 & 0.0200 & 0.6970 & -0.1160 \\
\hline $\mathrm{P}_{8} \times \mathrm{P}_{10}$ & 105.7470 & -0.1380 & -0.0590 & -2.6700 & 0.2580 \\
\hline $\mathrm{P}_{9} \times \mathrm{P}_{9}^{10}$ & -553.0000 & 0.0140 & -0.0300 & 7.4610 & 0.7860 \\
\hline $\mathrm{P}_{9} \times \mathrm{P}_{10}^{9}$ & -451.1200 & -0.0130 & -0.0450 & -0.2480 & -0.4730 \\
\hline $\mathrm{P}_{10} \times \mathrm{P}_{10}$ & -585.9190 & -0.1070 & -0.1050 & 4.7110 & 0.2690 \\
\hline
\end{tabular}

$\mathrm{P}_{1}=\mathrm{PR} 023 ; \mathrm{P}_{2}=\mathrm{PR} 024 ; \mathrm{P}_{3}=\mathrm{PR} 036 ; \mathrm{P}_{4}=\mathrm{UEM} \mathrm{J} 1 ; \mathrm{P}_{5}=\mathrm{PR} 045-1 ; \mathrm{P}_{6}=\mathrm{PR} 045-2 ; \mathrm{P}_{7}=\mathrm{PR} 045-3 ; \mathrm{P}_{8}=\mathrm{PR} 087-$ $1 ; \mathrm{P}_{9}=\mathrm{PR} 087-2 ; \mathrm{P}_{10}=\mathrm{PR} 087-3 ; \mathrm{GY}=$ grain yield; $\mathrm{PH}=$ plant height; $\mathrm{EH}=$ ear height; $\mathrm{PE}=$ popping expansion; $\mathrm{FL}=$ days to silking. 
The genitors $\mathrm{P}_{1}, \mathrm{P}_{2}, \mathrm{P}_{3}$, and $\mathrm{P}_{4}$ had higher and negative $\hat{\mathrm{s}}_{\mathrm{ii}}$, which indicated high genetic divergence for GY, $\mathrm{PH}$ and $\mathrm{EH}$ in comparison to the other inbred lines.

\section{DISCUSSION}

Genetic variability between genotypes was detected for GY and PE, and the variability from inbred lines (data not shown) permitted the selection and formation of promising hybrids. In the present experiment, all hybrids performed better than the commercial genotypes. Studies in South and South-eastern Brazil also demonstrated high GY differences between sites for Zélia (Sawazaki et al., 2000) and IAC112 (Freitas Júnior et al., 2006; Rangel et al., 2007, 2008). These authors showed that GY is a trait highly influenced by environmental conditions, confirming the importance of regional-breeding programs.

Although some variation in agronomic characteristics is based on the significance of genotypes versus environments, there are no constraints in recommending hybrids for both sites because the $\mathrm{P}_{1} \times \mathrm{P}_{3}$ and $\mathrm{P}_{3} \times \mathrm{P}_{7}$ were the best hybrids at both locations. Additionally, $\mathrm{P}_{2}$ demonstrated a desirable response at both sites, which made it possible to infer about other combinations with the potential of releasing commercial genotypes because the combination $\mathrm{P}_{2} \times \mathrm{P}_{4}$, for example, produced $3,667.00 \mathrm{~kg} / \mathrm{ha}$ and had a $\mathrm{PE}$ of $33.22 \mathrm{~mL} / \mathrm{g}$.

Hybrids and lines had a PH with important indices because North and Northwestern Rio de Janeiro have high incidence of winds capable of dislodging the plants, and dislodging reduces crop yield. Popcorn plants are more prone to dislodging than is common maize. Ear height is important because this trait is also highly related to plant dislodging (Ji et al., 2006).

The $\hat{\mathrm{s}}_{\mathrm{ij}}$ for PE were low and close to the general mean. Therefore, additive effects were predominant for PE, although several researchers have reported the presence of bi-directional dominance (Andrade et al., 2002; Viana and Matta, 2003; Simon et al., 2004; Freitas Júnior et al., 2006; Scapim et al., 2006; Miranda et al., 2008). The inheritance of bi-directional dominance also explains the low heterosis for PE in the national population.

The inbred lines $\mathrm{P}_{8}, \mathrm{P}_{10}, \mathrm{P}_{2}$, and $\mathrm{P}_{9}$, which had superior $\mathrm{PE}$ in both environments, could be recommended to produce hybrids with phenotypic stability. The hybrid $\mathrm{P}_{1} \times \mathrm{P}_{3}$ could be recommended because of the positive estimates for GY and PE. The hybrid $\mathrm{P}_{2} \times \mathrm{P}_{4}$ had a positive estimate of $\hat{s}_{\mathrm{ij}}$ for PE, but had a poor estimate for GY, which puts it in the eighth order of the GY ranking. $P_{3} \times P_{7}$ had a positive estimate of $\hat{s}_{i j}$ for GY, but negative estimate for PE $(-0.1390)$, which means negative heterosis. In this case, the hybrid recommendation should be based on the average values (Scapim et al., 2006). Therefore, the best hybrids for improving GY and PE were $\mathrm{P}_{1} \times \mathrm{P}_{3}$ and $\mathrm{P}_{2} \times \mathrm{P}_{4}$, which had GYs and PEs of 3,316.67 kg/ha and 32.17 $\mathrm{mL} / \mathrm{g}$, and $3,662.67 \mathrm{~kg} / \mathrm{ha}$ and $31.44 \mathrm{~mL} / \mathrm{g}$, respectively. They had positive values of $\mathrm{s}_{\mathrm{ij}}$ for GY and PE. These hybrids could also be recommended to increase GY and PE by reciprocal recurrent selection.

Although the number of parameters in Griffing's method (model II) is small, it is as efficient as the Gardner and Eberhart model (1966), not only because $\hat{\mathrm{g}}_{\mathrm{i}}=1 / 2 \hat{V}_{i}+\hat{h}_{i}$, but also because of the underlying information in the $\hat{s}_{\mathrm{ii}}$ effects. For example, the magnitude of $\hat{s}_{\mathrm{ii}}$ indicates variety heterosis, and a larger $\hat{\mathrm{s}}_{\mathrm{ii}}$ indicates a greater distance between genitor $i$ and the average frequency from the other participants in the diallel. Therefore, the greater the divergence between genitor $i$ and the other parents, the greater are the heterotic effects of varieties on their hybrids (Cruz et al., 2004). Furthermore, the sign of the $\hat{\mathrm{s}}_{\mathrm{ii}}$ may indicate the presence 
of unidirectional dominance. For example, a negative $\hat{\mathrm{s}}_{\mathrm{ii}}$ indicates positive deviation of the dominance; therefore, the dominant genes contributed to increase the trait estimate, unlike the presence of both negative and positive signs, which indicates bi-directional dominance (Cruz and Vencovsky, 1989; Cruz et al., 2004). In summary, except for the $\mathrm{P}_{6}$ line, the negative sign of GY indicated unidirectional dominance; therefore, the dominant genes contributed to the increase in productivity. Second, a similar unidirectional dominance was detected for PE, but the estimate of this trait was reduced by the genes. Third, positive heterosis for GY dominated the hybrid combinations in contrast to the responses for PE. Finally, higher estimates for GY but not for PE indicated that the genitors were more divergent for crop yield than for popping expansion.

Therefore, high crop yield and proper popping expansion may be achieved through lines with satisfactory allelic complementation as evaluated by Griffing's method, and even when there is positive unidirectional dominance for PE. Similarly, there are other responses from openpollinated varieties (Vieira et al., 2009b) or hybrids (Vieira et al., 2009c) from popcorn lines.

\section{ACKNOWLEDGMENTS}

Research supported by the National Council of Scientific and Technological Development $(\mathrm{CNPq})$ and Research Foundation of the State of Rio de Janeiro (FAPERJ).

\section{REFERENCES}

Amaral Júnior AT, Casali VWD, Cruz CD and Finger FL (1999). Genetic inferences on yield and quality of tomato in a diallel cross. Pesq. Agropec. Bras. 34: 1407-1416.

Amaral Júnior AT, Freitas Junior SP, Rangel RM, Pena GF, et al. (2010). Improvement of a popcorn population using selection indexes from a fourth cycle of recurrent selection program carried out in two different environments. Genet. Mol. Res. 9: 340-347.

Andrade AA, Cruz CD, Scapim CA, Pinto RJB, et al. (2002). Diallel analysis of the combining ability of popcorn cultivars. Acta Sci. Agron. 24: 1197-1204.

Arnhold E, Viana JMS, Silva RG and Mora F (2009). Relative efficiencies of selection methods of inbred families in popcorn. Acta Sci. Agron. 31: 203-207.

Bison O, Ramalho MAP, Resende GDSP, Aguiar AM, et al. (2007). Combining ability of elite clones of Eucalyptus grandis and Eucalyptus urophylla with Eucalyptus globulus. Genet. Mol. Biol. 30: 417-422.

Burnham Larish LL and Brewbaker JL (1999). Diallel analyses of temperate and tropical popcorns. Maydica 44: 279-284.

Cavalcanti JJV, Pinto CABP, Crisóstomo JR and Ferreira DF (2000). Diallel analysis to evaluate interpopulational cashew tree hybrids. Pesq. Agropec. Bras. 35: 1567-1575.

Cruz CD (2006). GENES Software: Version Windows: Computer Application in Genetics and Statistics. Universidade Federal de Viçosa, Viçosa.

Cruz CD and Vencovsky R (1989). Comparison of some methods of diallel analysis. Rev. Bras. Genet. 12: 425-438.

Cruz CD, Regazzi AJ and Carneiro PCS (2004). Biometric Models Applied to Genetic Breeding. Universidade Federal de Viçosa, Viçosa.

Dandolini TS, Scapim CA, Amaral Júnior AT, Mangolin CA, et al. (2008). Genetic divergence in popcorn lines detected by microsatellite markers. Crop Breed. Appl. Biotechnol. 8: 313-320.

Freitas Júnior SP, Amaral Júnior AT, Pereira MG, Cruz CD, et al. (2006). Combining ability in popcorn by circulant diallel. Pesq. Agropec. Bras. 41: 1599-1607.

Freitas Júnior SP, Amaral Júnior AT, Rangel RM and Viana AP (2009). Genetic gains in popcorn by full-sib recurrent selection. Crop Breed. Appl. Biotechnol. 9: 1-7.

Gardner CO and Ebehart SA (1966). Analysis and interpretation of the variety cross diallel and related populations. Biometrics 22: 439-452.

Gouis JL, Beghin D, Heumez E and Pluchard P (2002). Diallel analysis of winter wheat at two nitrogen levels. Crop Sci. 42: 1129-1134. 
Griffing B (1956). Concept of general and specific combining ability in relation to diallel crossing systems. Aust. J. Biol. Sci. 9: 463-493.

Hallauer AR and Miranda Filho JB (1995). Quantitative Genetics in Maize Breeding. 2nd edn. Iowa State University Press, Ames.

Jaramillo G, Morante N, Pérez JC, Calle F, et al. (2005). Diallel analysis in cassava adapted to the midaltitude valleys environment. Crop Sci. 45: 1058-1063.

Ji HC, Cho JW and Yamakawa T (2006). Diallel analysis of plant and ear heights in tropical maize (Zea mays L.). J. Fac. Agric. Kyushu Univ. 51:233-238.

Marin SLD, Pereira MG, Amaral Júnior AT, Martelleto LAP, et al. (2006). Partial diallel to evaluate the combining ability for economically important traits of papaya. Sci. Agric. 63: 540-546.

Melani MD and Carena MJ (2005). Alternative maize heterotic patterns for the northern corn belt. Crop Sci. 45: 2186-2194.

Miranda GV, Souza LV, Galvão JCC, Guimarães LJM, et al. (2008). Genetic variability and heterotic groups of Brazilian popcorn populations. Euphytica 162: 431-440.

Moterle LM, Scapim CA, Braccini AL, Rodovalho MA, et al. (2008). Influence of water stress on the physiological performance of seeds of simple hybrids of popcorn. Cienc. Agrotec. 32: 1810-1817.

Pereira LK, Mangolin CA, Scapim CA, Pacheco CAP, et al. (2006). Malate dehydrogenase isozyme patterns in four cycles of half-sib selection from CMS-43 popcorn variety (Zea mays L.). Maydica 51: 561-566.

Pereira LK, Scapim CA, Mangolin CA, Machado MFPS, et al. (2008). Heterozygosity following half-sib recurrent selection in popcorn using isoenzyme markers. Electron. J. Biotechnol. 11: 108-115.

Rangel RM, Amaral Junior AT, Viana AP, Freitas Júnior SP, et al. (2007). Prediction of popcorn hybrid and composite means. Crop Breed. Appl. Biotechnol. 7: 287-295.

Rangel RM, Amaral AT Jr, Scapim CA, Freitas SP Jr, et al. (2008). Genetic parameters in parents and hybrids of circulant diallel in popcorn. Genet. Mol. Res. 7: 1020-1030.

Ricci GL, Silva N, Pagliarini MS and Scapim CA (2007). B chromosomes in popcorn (Zea mays L.). Genet. Mol. Res. 6: 137-143.

Sawazaki E, Paterniani MEAGZ, Castro JL, Gallo PB, et al. (2000). Inbred line potentials for the synthesis of new popcorn hybrids. Bragantia 59: 143-151.

Scapim CA, Pacheco CAP, Tonet A, Braccini AL, et al. (2002). Diallel analyses and heterosis in popcorn varieties. Bragantia 61: 219-230.

Scapim CA, Pinto RJB, Amaral Júnior AT, Mora F, et al. (2006). Combining ability of white grain popcorn populations. Crop Breed. Appl. Biotechnol. 6: 136-143.

Scapim CA, Pacheco CAP, Amaral Júnior AT, Vieira RA, et al. (2010). Correlations between the stability and adaptability statistics of popcorn cultivars. Euphytica 174: 209-218.

Silva MP, Amaral Júnior AT, Rodrigues R, Pereira MG, et al. (2004). Genetic control on morphoagronomic traits in snap bean. Braz. Arch. Biol. Technol. 47: 855-862.

Silva TA, Pinto RJB, Scapim CA, Mangolin CA, et al. (2009). Genetic divergence in popcorn genotypes using microsatellites in bulk genomic DNA. Crop Breed. Appl. Biotechnol. 9: 31-36.

Silva VQR, Amaral Júnior AT, Scapim CA, Freitas Júnior SP, et al. (2010). Inheritance for economically important traits in popcorn from distinct heterotic groups by Hayman's diallel. Cereal Res. Commun. 38: 273-285.

Simon GA, Scapim CA, Pacheco CAP, Pinto RJB, et al. (2004). Inbreeding depression in popcorn populations. Bragantia 63: 55-62.

Trindade APR, Pinto RJB, Amaral Júnior AT, Mangolin CA, et al. (2010). Genetic diversity of breeding popcorn lines determined by SSR markers. Electron. J. Biotechnol. 13: 1-9.

Vendruscolo ECG, Scapim CA, Pacheco CAP, Oliveira VR, et al. (2001). Adaptability and stability of popcorn cultivars in the central-south of Brazil. Pesq. Agropec. Bras. 36: 123-130.

Viana JMS and Matta VFP (2003). Analysis of general and specific combining abilities of popcorn populations, including selfed parents. Genet. Mol. Biol. 26: 465-471.

Vieira RA, Tessmann DJ, Scapim CA, Hata FT, et al. (2009a). Genetic resistance of new popcorn hybrids to foliar diseases. Crop Breed. Appl. Biotechnol. 9: 140-146.

Vieira RA, Souza Neto IL, Bignotto LS, Cruz CD, et al. (2009b). Heterotic parametrization for economically important traits in popcorn. Acta Sci. Agron. 31: 411-419.

Vieira RA, Rodovalho MA, Scapim CA, Tessmann DJ, et al. (2009c). Agronomic performance of new popcorn hybrids in Northwestern Paraná State, Brazil. Acta Sci. Agron. 31: 29-36.

Vilela FO, Amaral Júnior AT, Pereira MG, Scapim CA, et al. (2008). Effect of recurrent selection on the genetic variability of the UNB-2U popcorn population using RAPD markers. Acta Sci. Agron. 30: 25-30. 